\title{
Pasien TBC yang Tidak Patuh Obat, Selain Risiko Resistensi Juga Memerlukan Banyak Biaya
}

\author{
Eko Aprilianto \\ Fakultas Farmasi, Universitas Sanata Dharma, Sleman, Yogyakarta \\ Terbit online : 2 Desember 2016
}

\section{Abstrak}

Tuberkulosis (TBC) merupakan salah satu penyakit menular yang disebabkan karena adanya infeksi akut atau kronis yang disebabkan oleh Mycobacterium tuberculosis. Dari sudut pandang farmakoekonomi, kita diajak untuk melihat suatu permasalahan dengan membandingkan segi biaya yang dikeluarkan, resiko yang ada dan hasil (outcome) yang didapatkan dari suatu sistem kesehatan yang salah satu contohnya mengambil kebijakan dalam terapi agar berjalan efektif dan efisien. Dalam kasus TBC di Indonesia, pasien TBC yang tidak patuh konsumsi obat, selain berisiko resistensi obat juga terbukti memerlukan lebih banyak biaya yang harus dikeluarkan. Pemilihan terapi pengobatan metode Pasive Case Treatment (PCT) juga telah memperlihatkan pentingnya kepatuhan terapi obat yang dapat membuat terapi TBC yang lebih efisien dari sisi terapi dan biaya.

Keyword : Tuberkulosis, farmakoekonomi, terapi obat

\section{Pendahuluan}

Tuberkulosis (TBC) merupakan salah satu penyakit menular yang disebabkan karena adanya infeksi akut atau kronis yang disebabkan oleh Mycobacterium tuberculosis. Penyakit ini paling sering menyerang paru-paru walaupun pada sepertiga kasus menyerang organ tubuh lain dan ditularkan orang ke orang.

TBC juga merupakan salah satu penyakit tertua yang diketahui menyerang manusia. Jika diterapi dengan benar tuberkulosis yang disebabkan oleh kompleks Mycobacterium tuberculosis, yang peka terhadap obat, praktis dapat disembuhkan. Tanpa terapi tuberkulosa akan mengakibatkan kematian dalam lima tahun pertama pada lebih dari setengah kasus.

\section{Prevalensi TBC di Indonesia}

Indonesia menempati peringkat keempat diantara negara-negara TBC tertinggi di dunia. Laporan WHO tahun 2004 menyatakan bahwa terdapat 8,8 juta kasus baru tuberkulosis pada tahun 2002, sepertiga penduduk dunia telah terinfeksi kuman tuberkulosis dan menurut regional WHO jumlah terbesar kasus ini terjadi di Asia Tenggara yaitu 33\% dari seluruh kasus di dunia.

Indonesia berada dalam peringkat ketiga terburuk di dunia untuk jumlah penderita TBC. Setiap tahun muncul 500 ribu kasus baru dan lebih dari 140 ribu lainnya meninggal. 


\section{Terapi bagi penderita TBC}

Pengobatan Tuberkulosis berlangsung cukup lama yaitu setidaknya 6 bulan pengobatan dan selanjutnya dievaluasi oleh dokter apakah perlu dilanjutkan atau berhenti, karena pengobatan yang cukup lama seringkali membuat pasien putus berobat atau menjalankan pengobatan secara tidak teratur dimana dapat mengakibatkan pengobatan tidak berhasil dan kuman menjadi kebal disebut MDR ( multi drugs resistance), kasus ini memerlukan biaya berlipat dan lebih sulit dalam pengobatannya sehingga diharapkan pasien disiplin dalam berobat setiap waktu demi pengentasan tuberkulosis di Indonesia.

Terapi bagi penderita TBC pun tidak bisa dikatakan sederhana dan mudah karena untuk penatalaksanaan terapi bagi pasien TBC, obat yang dibutuhkan lebih dari 2 dan adanya kombinasi obat. Terapi bagi pasien yang pertama kali terkena TBC dan mengalami putus obat juga tidak sama. Oleh sebab itu biaya yang dikeluarkan untuk mengatasi penyakit TBC ini tidak murah.

\section{Terapi Penyakit TBC dari Sudut Pandang Farmakoekonomi}

Dari sudut pandang farmakoekonomi kita diajak untuk melihat suatu permasalahan dengan membandingkan segi biaya yang dikeluarkan, resiko yang ada dan hasil (outcome) yang didapatkan dari suatu sistem kesehatan yang salah satu contohnya mengambil kebijakan dalam terapi agar berjalan efektif dan efisien.

Dilihat dari angka kejadian TBC di Indonesia serta lama terapi yang akan dijalani oleh pasien TBC, maka penyakit TB merupakan salah satu penyakit yang memerlukan banyak biaya, baik yang dikeluarkan oleh pemerintah maupun oleh masyarakat sendiri. Sebagai contoh pada tahun 2009 kebutuhan total biaya penanggulangan TB untuk setahun adalah sebesar 621,5 miliyar rupiah dan pemerintah hanya mampu menanggung sebesar 145 miliyar rupiah dari total tersebut. Dilihat dari besarnya biaya tersebut maka studi farmakoekonomi diperlukan untuk melihat perbandingan jumlah biaya yang dikeluarkan terhadap outcome terapi yang didapat. Studi farmakoekonomi yang dilakukan Syarupuddin, M (2015) di RS Pemerintah di Jakarta mengemukakan bahwa terdapat 31 pasien yang mengalami TBC kategori I yang mengeluarkan total biaya terapi selama 6 bulan sebesar Rp. 57.149 .647 sehingga rata-rata perorang mengeluarkan biaya sebesar Rp. 1.843 .537 dengan tingkat kesembuhan sebesar 13 orang $(41,9 \%)$ sehingga dibutuhkan biaya Rp. 4.396 .127 per orang selama 6 bulan tarapi untuk memperoleh kesembuhan.

Studi tersebut juga mengemukakan hanya 31 pasien $(68,9 \%)$ yang patuh menjalani terapi selama 6 bulan dari 50 pasien yang awal terdata. Data tersebut menunjukan masih ada pasien yang cendenung berhenti berobat ketika merasakan kondisinya sudah membaik padahal hal tersebut dapat memacu terjadinya resistensi karena terapi yang tidak tuntas yang memungkinkan juga munculnya penyakit TBC lagi.

Artinya, jika pasien patuh saja, biaya yang dikeluarkan tidak sedikit, apabila pasien tidak patuh dan harus mengulangi terapi yang dilakukan maka pastilah biaya yang dikeluarkan akan 2 x lipat biaya diatas atau mungkin lebih. 
Alternatif untuk mengatasi masalah tersebut adalah menerapkan ACT (Active Case Treatment) yang merupakan cara pengobatan baru dengan tujuan mempermudah akses, membantu dari sisi ekonomi dan meningkatkan kualitas hidup penderita TBC dengan cara pemanfaatan kader terlatih datang ke rumah pasien secara teratur untuk memberikan OAT dan konseling pada mereka, sehingga hambatan yang terjadi pada cara PCT dapat dianulir.

Studi yang dilakukan Ni Ketut Ardani (2012) mengemukakan bahwa metode ACT lebih cost effective dibanding metode PCT (Pasive Case Treatment) yang mana mengharuskan pasien TBC datang atau berkunjung ke Unit Pelayanan Kesehatan pada hari dan jam yang telah ditentukan untuk mendapatkan obatanti TBC yang selanjutnya disebut OAT.

Dengan mengharuskan pasien datang secara teratur ke UPK menyebabkan akses atau kemudahan pasien dapat terhalang oleh kendala atau hambatan yang dialami pasien dari sisi ekonomi, psikologi, dan pendidikan pasien tersebut yang berujung pada ketidakpatuhan pasien sehingga biaya terapi yang dikeluarkan besar tetapi hasil yang didapatkan jauh dari target atau harapan dari keselerasan biaya yang dikeluarkan.

Hasil studi menunjukkan 21 responden metode PCT mengeluarkan total biaya sebesar Rp. 29.907.390 dengan peningkatan QoL(quality of life) sebesar 40,35 sedangkan 21 responden metode ACT mengeluarkan total biaya sebesar Rp. 17.070.894 dengan peningkatan nilai QoL(quality of life) sebesar 565,64. Perhitungan CER yang didapat adalah 35,295 untuk metode PCT dan 14.377 untuk metode ACT yang menyatakan bahwa untuk meningkatkan satu nilai QoL dibutuhkan Rp. 35,295 untuk metode PCT dan Rp. 14.377 untuk metode ACT sehingga metode ACT lebih Cost Effective dibanding metode PCT.

\section{Kesimpulan}

Sudut pandang dari studi farmakoekonomi mengajak kita untuk tahu bagaimana caranya atau mengambil tindakan dalam memutuskan teknis pengobatan yang memiliki hasil (outcome) terbaik dengan biaya yang dikeluarkan seminimal mungkin. Oleh karena itu, penting bagi kita untuk mengetahui peranan farmakoekonomi dalam pengambilan keputusan atau tindakan sehingga dapat tercapai hasil yang efisien dan ekonomis.

Dalam kasus TBC di Indonesia, pasien TBC yang tidak patuh konsumsi obat, selain berisiko resistensi obat juga terbukti memerlukan lebih banyak biaya yang harus dikeluarkan. Pemilihan terapi pengobatan metode PCT juga telah memperlihatkan pentingnya kepatuhan terapi obat yang dapat membuat terapi TBC yang lebih efisien dari sisi terapi dan biaya.

\section{Daftar pustaka}

Ardani, N.K., 2012, Active Case Treatment Lebih Cost Effective untuk Pengobatan TB Paru Tahap Awal, Dinas Kesehatan Kabupaten Jember, Indonesia, hal. 188,191

Syaripuddin, M., S. Si, Apt, MKM, dan Tim. Analisis Biaya dan Hasil Pengobatan Tuberkulosis Paru Kategori Satu Pasien Dewasa Di Rumah Sakit Pemerintah. Kementrian Kesehatan. Hal. 35, 36.

PDPI, 2002, Pedoman Diagnosis \& Penatalaksanaan Tuberkulosis di Indonesia, Indonesia, hal.1-2.

Artikel ini telah terbit secara online di http://farmasetika.com/2016/12/02/pasien-tbc-yang-tidakpatuh-obat-selain-risiko-resistensi-juga-memerlukan-banyak-biaya/ 